\title{
The Diffusion of Performance Evaluation Measures: An Empirical Study in Jordanian Banks
}

\author{
Munther Al-Nimer ${ }^{1}$, Nimer Sleihat ${ }^{2}$, Haitham Al Abbadi ${ }^{2} \&$ Soud Almahamid $^{2}$ \\ ${ }^{1}$ Faculty of Economics and Administrative sciences, Applied Science University, Bahrain, Jordan \\ ${ }^{2}$ Faculty of Business, Amman Arab University, Amman, Jordan \\ Correspondence: Soud Almahamid, Faculty of Business, Amman Arab University, Amman, Jordan. Tel: \\ 962-777-732-235. E-mail: soud.almahamid@ahu.edu.jo
}

$\begin{array}{lr}\text { Received: March 28, } 2012 & \text { Accepted: May 25, } 2012 \quad \text { Online Published: July 16, } 2012 \\ \text { doi:10.5539/ijbm.v7n14p76 } & \text { URL: http://dx.doi.org/10.5539/ijbm.v7n14p76 }\end{array}$

\begin{abstract}
This research aims to provide a view of the present role of performance evaluation measures, to identify the extent of usage of performance evaluation measures, and finally to examine the contingent variables in order to find out their effect upon the extent of usage in the Jordanian banks. In order to achieve these objectives, the research used a questionnaire method; 80 (out of 140) valid questionnaires were returned, giving a (57.14\%) response rate. Several statistical tests were used to analyze the data, namely, descriptive and bivariate correlation analysis (Kendall's tau test). The results revealed that there is a lack of use of non-financial measures that are considered as contemporary management accounting practices. However, the financial measures were considered as the highest practice being utilised. In addition, the results confirmed the hypothesized relationships between contingency variables and the extent of usage, namely; age of the company; net sale growth, number of employees; sophistication of operations; professional certificates; and academic certificates. Finally, it can be concluded that the traditional Performance evaluation measures are still widely used.
\end{abstract}

Keywords: performance evaluation measures, management accounting, Jordanian banks, Jordan

\section{Introduction}

Academics and professionals agree on the significance of performance measure selection decisions for any organization, since unwisely selected measures usually lead to serious risks that include unsuccessful implementation of an organization's strategy, unsound judgments and thus undesirable consequences. These hazards could be avoided by developing reliable measurement methodologies that encompass non-financial measures, characterized by value relevance and predictive value, to be used as reliable indicators of prospective shareholder value (Kaplan \& Norton, 1996; Ittner \& Larcker, 1998; Chambers, 2003).

Therefore, several studies have emphasized the need to pay attention to performance evaluation measures, for instance, (Ewert \&Wagenhofer, 2006; Adelegan, 2000; Carmona, 2006; Abdel-Kader \& Luther, 2006; Islam \& Kantor, 2005), and many studies were undertaken in order to trace the history development of management accounting particularly, performance evaluation measures, (Spraakman, 1999; Fleischman \& Tyson, 2006; Okano \& Suzuki, 2006; Näsi \& Rohde 2006; Ahmad B. Abdel- Maksoud, 2004); Strauss 1992; Spraakman \& Margret, 2005).

Other studies were carried out in order to investigate the influence of the external and internal factors on the extent to which Performance evaluation measures were used, and the benefit of using these measures by using a variety of theories such as an institutional theory, (Hussain \& Gunasekaran, 2002), and contingency theory, (Flacke \& Segbers, 2005; Fry et al. 1995; Burns et al., 2004; Ashton et al., 1995; Silvola, 2005; Haldma \& Laats, 2002; Abdel-Kader \& Luther, 2008), and others. There are a limited number of studies focusing on Performance evaluation measures in developing countries, (Adelegan, 2000; Sulaiman et al, 2004; Ismail, 2007; Triest \& Elshahat, 2007; Kattan et al., 2007; Billings \& Capie, 2004). Therefore, it's worthwhile to investigate Performance evaluation measures in Jordanian Banks in order to fill this shortage of studies. To sum up, researchers need to pay more attention to performance evaluation measures, which is a vital element providing firms with timely and accurate information. It is important to pursue the evolution and the changing market competition and all challenges by which firms are faced. 
At present within Jordan there is a lack of knowledge and research into management accounting practices in general and at present within Jordan there is a lack of knowledge and research into management accounting practices specifically, performance evaluation measures, (Hutaibat, 2005). Therefore, this is an area to be investigated. Consequently, the current research attempts to remedy this shortage of studies in Performance evaluation measures and fill the gap in the management accounting literature in developing countries and particularly in Jordan as a developing country. It also aims to provide a view of the present role of performance evaluation measures, to identify the extent of usage of performance evaluation measures, and finally to examine the contingent variables in order to find out their effect upon the extent of usage of Performance evaluation measures in the Jordanian banks.

\section{Literature Review}

\subsection{Performance Evaluation Measures Studies}

The debate in terms of management accounting has lost relevance to provide both managers and other information users with useful information; a lot of research has been done in respect of the role of management accounting and the changing of management accounting systems as discussed earlier. In the 1990s another dimension was added to the study of management accounting by focusing upon the scope of application of management accounting practices, the benefits of adoption, and the differences between countries in the adoption of management accounting practices (Shields et al., 1991; Kowalak, 2007; Clarke, 1997; Chan et al., 1997; Marelli et al., 2002; Christopher, 2004; Clarke et al., 1996).

Consequently, There are many studies which have been carried out to examine the level of adoption of Performance evaluation measures and the majority of these studies emphasized the significant role of these measures in the companies, and after reviewing some of these studies, the research concludes that there is a variety in the level of adoption of the Performance evaluation measures but the most adopted measures of the performance evaluation are the measures that are based on financial performance, here are some of these studies; a comparative study conducted between Japan and Australia found that Japanese companies used financial measures more than Australian companies (Wijewardena \& De Zoysa 1998).

According to Forde, Burnett et al. (2005) in the survey that attempted to explore and describe the status of adoption of management accounting practices, revealed that $25 \%$ of respondents adopted economic value added practice, and 37\% adopted benchmarking (internal and external) practice. Haldma and Laats (2002) claimed that there is wide adoption of performance measurement in most of the Estonian manufacturing companies by $68 \%$, based on different operating segments or divisions. They added that the majority of the companies monitored and evaluated the profits of different internal business units and products or product groups and $74 \%$ used profitability as a performance measurement indicator.

A study conducted by Hyvonen (2005) revealed that $80 \%$ of respondents adopted benchmarking of product characteristics, and $80 \%$ used benchmarking carried out within the wider organisation. In addition, the study revealed that $13 \%$ of respondents used the balance scorecard practice. In the developing countries a study in Egypt, conducted by Ismail (2007) indicated that the profit margin, as a financial measure, is the most commonly used performance measure with a mean score of 3.49 and customer satisfaction is the most commonly used non-financial measure of performance evaluation with a mean score of 3.58. Furthermore, the study revealed that $60.5 \%$ of respondent companies had adopted the balanced scorecard as a measure of performance evaluation.

Forsaith, Tilt et al. (2001) attempted to explore the current and future role of management accounting in South Australian companies, The study revealed that $57.5 \%$ of respondent companies used benchmarking, $27.3 \%$ used balanced scorecards, $54.7 \%$ used customer satisfaction, $65.8 \%$ used non financial measures, and finally just $14.3 \%$ of the respondent companies used residual income. Abdel-Kader and Luther (2006) reported that $76 \%$ of companies answered often or very often used financial measures, $11 \%$ of them used benchmarks practice, and $7 \%$ of them often or very often used economic value added or residual income. For the non-financial performance evaluation the study revealed that respondent companies found often and very often used them as the following, $38 \%$ for non-financial measures related to customers, $11 \%$ for non-financial measures related to employees, $26 \%$ for non-financial measures related to operations and innovation. Another study conducted in Italy found that $28 \%$ of respondent companies used integrated performance measurement, and $31 \%$ reported used benchmarks (Cinquini \& Tenucci 2006). A survey carried out by Garg, Ghosh et al. (2004) argued that the management accountants' role has changed and that they are increasingly perceived as business partners who focus on key strategic issues well beyond the boundaries of traditional finance.

Later, Mia and Ahmad (2005) reviewed the significant role of management accounting practices at the beginning of the $21^{\text {st }}$ century in terms of: supporting managers at a strategic level, change management, managing 
coordination, managerial development, achieving competitive advantage and corporate social responsibility. Their work indicated the necessity for management accounting practices to respond to modern challenges and improvements.

A recent survey has been carried out in 40 Egyptian private firms by using a questionnaire and interviews in order to investigate the current state and the use of costing information in terms of three aspects specifically, accuracy, satisfaction and development plans (Triest \& Elshahat, 2007). The survey noted the lack of research on management accounting practices in non-western countries and asserted that, therefore, the state of management accounting in these countries was limited. Additionally, the study revealed that the use and sophistication of costing information in Egypt is limited and that no advanced management accounting practices seem to be applied and the main purpose of the costing system was for pricing decisions rather than performance measurement, process improvement or cost reduction. The study considered that the shortage of usage of costing information due to the misunderstanding of western management accounting concepts (terminology) and that their cultures differ in such issues as motivation, resistance to change, attitudes to appraisal, the use of delegation, risk taking behavior and expected career structure. A conclusion drawn by Gupta and Gunasekaran (2005) indicated that the Internet and e-commerce have changed the way companies conduct their businesses, these changes motivate management accounting researchers to develop their costing and performance measurement systems.

\subsection{Contingency Theory and Performance Evaluation Measures}

The contingency approach to management accounting is based on the premise that there is no universally appropriate accounting system applicable equally to all organizations in all circumstances. Rather, it is suggested that the particular features of an appropriate accounting system will depend upon the specific circumstances in which an organization finds itself. In addition, how effective the design of an accounting system is depends on its ability to adapt to changes in external circumstances and internal factors. Thus contingency theory must identify specific aspects of an accounting system which are associated with certain defined circumstances and demonstrate appropriate matching (Otley, 1980).

Numerous studies have tested the contingency theory in management accounting. For instance, Haldma and Laats (2002) divided the contingency variables into two categories, internal variables (organizational aspects, technology and strategy) and external (business and accounting environment) and examined the extent to which these variables influence most of the studies examined the application of contingency theory to the management accounting discipline were devoted to common contingency factors e.g., technology, size, structure, strategy and national culture, organizational capacity to learn, external environment and competitors (Hoque \& Mia 2001; Waweru et al., 2004; Anderson \& Lanen, 1999; Haldma \& Laats 2002; Chenhall, 2003).

\subsubsection{Organization Size}

Organization size is considered as one of the variables that have been examined as a contingent variable in many disciplines. It is considered one of the most vital variables that influence management accounting information and practices in many ways, e.g. upon the management accounting practices change, usage, understanding and adoption decision. In order to find out the main factors that influence the sophistication level of costing systems a study by Al-Omiri and Drury (2007) of UK organizations from different sectors by using a postal questionnaire, indicated that organization size, intensity of the competitive environment, extent of the use of production technologies and the type of business sector are positively associated with levels of cost system sophistication. According to Chenhall (2003) the main five elements that were indicated as contingent variables and that have a major effect on management accounting are; environment, technology, organization size, structure, strategy and national culture. A study carried out by, Waweru, Hoque et al. (2004) that aimed to investigate predictors of management accounting change in South Africa. The study that came to the conclusion that organization size is one of major variables that influence management accounting change, beside decentralization, and organizational capacity to learn variables.

Joshi (2001) supported the view that size has a major influence in determining the adoption of newly developed management accounting practices and the other reason for low adoption are the conservative attitudes of Indian management and long term orientation. Finally, Cinquini and Tenucci (2006) indicated that organization size and competitive strategy as contingency variables influence the adoption of strategic management accounting practices. Based on the above discussions and literature, organization size is a worthwhile variable to be examined, particularly in terms of the adoption of performance evaluation practices. In addition, this variable is applicable in the Jordanian business environment due to the variation in size among the companies in the financial sector. Consequently, the current research will examine the organization size variable in order to find 
out the effect of this variable upon the extent of usage of Performance evaluation measures in the Jordanian banks. In this aspect the study addresses the research question in term of organization size as: What is the effect of organization size upon the adoption of performance evaluation measures?

\subsubsection{Sophistication Level of Operations}

Many researchers have examined the effect of diversity of productions upon the company performance, employees' productivity, and other variables. However, in terms of management accounting discipline there are not many researchers who have examined the diversity of production and associated it with management accounting research. The concept of the sophisticated level of operations that is used in the current study refers to the number of products or services that the company produces or provides to their customers, with the more products and services offered being viewed as indicative of a more sophisticated operation. In 2003, Chenhall (2003) noted the significant role planed by complexity of production in determining the type of management accounting practices, as he argued that the complexity of the production function and production processes have an effect on determining which type of costing system was used.

Similar findings are provided by a study undertaken by Haldma and Laats (2002) that placed emphasis on the important impact that production complexity had on management accounting practices, since the study indicated that each production requires different procedures, and this in turn influences the type of costing to be used. Kallunki and Silvola (2007) sought to examine the effect of the organizational life cycle stage on the use of activity-based costing and investigated whether the use of activity based costing varies among firms in different life cycle stages. One of the main findings of the study is that firms in the maturity and revival phases have a greater organizational size, lower profitability, a more diversified product/service range and have more often achieved a stock market listing as opposed to firms in the growth phase.

In contrast, a study conducted in UK, attempted to determine the main factors that influence the choice of product costing system. One of the variables that the study examined was product diversity as a contextual factor beside other variables, namely; cost structure, intensity of the competitive environment, size of the organization. The study revealed a contrasting conclusion to previous studies and claimed that there was no association to be found between the level of cost system sophistication and cost structure, product diversity and quality of information technology (Abdel-Kader \& Luther, 2008). According to the above studies, the sophistication level of operations is a significant variable to be examined in terms of the extent of usage of performance evaluation measures. In this context the study addresses the research question in terms of sophistication level of operations as: What is the effect of the sophistication level of operations upon the adoption of Performance evaluation measures?

\subsubsection{Professional Competence}

Many have indicated the momentous role that professional competence plays in dealing with practical life and to support the practitioners' capability to adequately deal with real life, and to change it. Professional competence in the current research refers to education level achieved and professional skills acquired by practitioners in management accounting. The current decade witnessed much technological changes. As a result, there has been a significant change in many disciplines, with management accounting being no exception (Burns, Hopper et al., 2004).Therefore, to accommodate these challenges, the role of education and learning in management accounting appear to be significant if it is to fulfill its role in assisting management to achieve its goals in the environment. Marge the provision of information is a vital resource (Woodbine, 2007). According to Bamber, Braun et al. (2007) management accounting requires specific skills of compliance, and to be more efficient and effective, to achieve the aims of management accounting information; it requires a solid knowledge of financial and managerial accounting, analytical skills, knowledge of how a business functions and oral and writing communication skills.

In the same context, a study carried out by Fowler, Tan et al. (2002) investigated the gap that exists between management accounting education and practice. The study revealed that practitioners place emphasis on traditional over contemporary techniques when selecting management accounting techniques used in their organizations. This suggests that academics cannot ignore the teaching of traditional management accounting techniques, although the development of new techniques is still of importance. The study claimed that non-adoption of management accounting techniques by practitioners does not necessarily mean that the techniques are irrelevant and inoperable. Burns, Hopper et al. (2004) in a study that discussed the changes that occurred in management accounting in the UK, claimed that the industry must look at greater sustained involvement in higher education and they suggested reforms of topics covered in syllabuses and quality systems in education. A study conducted in China by Woodbine (2007) claimed the necessity of reform and changes in 
the accounting education and education practices to be capable of accommodating the needs of a rapidly expanding number of local and international business entities, and of providing a more efficient means for disseminating knowledge. Cooper (2006) laid stressed on the changes in the purpose of the management accountant reflected and raised the breadth and diversity of knowledge needs for management accounting.

A way of changing and developing management accounting education is to change the skills that management accountants have to acquire; analytical(interpretive), broad business knowledge, team work, oral communication, integrating financial and non-financial information, information technology knowledge, professional ethical, presentational and finally interpersonal (Burns, Hopper et al., 2004; Siegel, 2000; Lord \& Robertson, 2006). Likewise Palmer, Ziegenfuss et al. (2004) indicated that accounting information is continually changing and recommended that educators have to design international knowledge, skills and abilities of auditors and accountants, such as communication skills, interpersonal skills, general business knowledge, accounting knowledge, problem-solving skills, information technology, personal attitude and capability, and computer skills

Another study by Joshi and Bremser (2004) reached the same conclusion in terms of the skills that accountants have to possess such as; communication skills, analytical skills and managerial skills. Ahmed (2003) in a study which examined the level of information technology skills that the accounting curriculum included suggested that the emphasis should be on the application of IT rather than on traditional computer science. Unlike the above suggestion in terms of the information technology (IT) skills that the management accountant has to learn and possess, results from a new study conducted by Chandra.A, Cheh. J. et al. (2007) attempted to explore the current use of information technology content in management accounting education. It was found that there is a growing gap between the (IT) skills demanded of management accountants and those supplied by higher education. In terms of developing personal skills, and their effect on adoption management accounting practices, in a study prepared by Forsaith, Tilt et al. (2001) to explore how current management accountants view their present and future role, they indicated that more emphasis needs to be placed on developing personal skills rather than technical skills, and that there is a need for more emphasis on the 'management' than the 'accounting'.

A study conducted to discover the extent to which traditional and contemporary management accounting techniques are being used in four Asian countries (Singapore, Malaysia, China, and India) indicated that the lack of awareness of new techniques, and the lack of expertise and a shortage of qualifications in management accounting, affected the lack of adoption of the new techniques (Sulaiman \& Ahmad et al. 2004). Silvola (2005) in a study that attempted to examine the effect of the Chief Executive Officers (CEO) education level, the study revealed a significant effect of the level of education on the adoption of management accounting practices. To sum up, there is a strong argument in terms of the effect of professional competence in management accounting practices, particularly in terms of the adoption of sophisticated management accounting practices. Therefore, the current research will examine this critical element and apply it to explain and to investigate its effect to the extent of usage of Performance evaluation measures in the Jordanian banks. In this aspect the study addresses the research question in term of level of education as: What is the effect of professional competence upon the performance evaluation measures?

\section{Methodology}

\subsection{Measurement of Contingency Variables}

In terms of examining the effect of contingency variables on the extent of usage of performance evaluation measures, the research measured these variables through asked the respondents questions that related to the respondents background in order to examine the impact of contingent variables upon extent usage of Performance evaluation measures as follows:

\subsubsection{Organization Size}

The organization size has been examined in several studies and considered as a vital element in terms of the adoption of more sophisticated management accounting practices including performance evaluation measures, for instance; Chenhall (2003), Waweru, Hoque et al. (2004), and Cinquini \& Tenucci (2006). Thus, current research measured the organization size by asking the respondents three questions to determine; age of the company since establishment, net sale growth; and the number of employees in the respondent companies.

\subsubsection{Sophistication of Operations Variable}

The sophistication of operations has been considered as a significant factor that influences the adoption of performance evaluation measures. This was confirmed in the review of the literature where it was revealed that most of the studies that have examined this variable have done on a manufacturing environment (Haldma \& Laats, 2002; Chenhall, 2003; Kallunki \& Silvola, 2007). Therefore, the current research examined this variable 
in the banking environment where the banking sector produced a variety both services and products. Consequently, the current research measured the sophistication of operations by asking the respondents to determine the number of products or services that the company produces.

\subsubsection{Professional Competence Variable}

The professional competence, as discussed earlier in the literature review section, can have a direct and significant effect on management accounting practices; including performance evaluation measures terms of adoption and development (Woodbine, 2007; Bamber, Braun et al., 2007; Fowler, Tan et al., 2002). Therefore, the research measured the effect of professional competence upon the extent of usage of Performance evaluation measures in the Jordanian banks by asking questions to determine the acquisition of academic qualifications and professional certificates by listing the number of academic quantifications and professional certificates and asked the respondents to determine the number of employees including himself having possession of quantifications and certificates.

\subsection{Measurement of Performance Evaluation Measures}

According to the objectives of the research, and in order to achieve those objectives, the research will ask the respondents to respond in the following question areas:

- The degree of usage of each of the measures, and the categories of the measures, to ensure understanding of the measures, and to which categories they belong.

- The importance of each practice to discover the tendency to adopt each of them and how important each measure is in planning for the future in terms of adopting the measures.

These question areas were based on ranking of the usage and the importance of each of the measures based on a Likert scale.

\subsection{Data Collection}

To attain the research objectives, the research utilized a self administration questionnaire in order to identify the current status of Performance evaluation measures in the Jordanian banks. The Jordanian banks were selected as the population of the research which comprised of all the banks. With reliance on the Ministry of Industry and Trade records at February 2008, the banking sector contains 14 banks. The findings of the research are based on 80 respondents who completed the questionnaire that gives $(57.14 \%)$ response rate that is considered a high response rate, and gives more confidence to the validity and reliability of the questionnaire results.

\section{Main Findings}

\subsection{The Extent of Usage and Importance of Performance Evaluation Measures}

The Performance evaluation measures were examined by asking the respondents two questions, one in terms of the extent of usage of these measures and the other in terms of the importance of these measures in orders to predict the future trend of the respondent companies regarding adopting these measures. The first question was formulated based on a five-point Likert scale in order to examine the extent of usage; never, rarely, sometimes, often, and very often and the second question was formulated based on a three-point Likert scale in order to examine the importance of the Performance evaluation measures in the Jordanian banks. Accordingly, this part will discuss the results of these two questions and supporting the discussion with studies which have been carried out in the management accounting field and particularly in performance evaluation measures. From the analysis of the first question, related to the extent of usage of the six listed performance evaluation measures, respondents rated the financial measures as the highest practice that is utilised in their companies since $78.1 \%$ of respondents ranked it often and vey often used, however, financial measures is classified as one of the traditional management accounting practices.

According to Table 1 below there is moderately usage of the non-financial measures related to operations and innovation as $64.7 \%$ of respondents answered they often and very often used it. Unsurprisingly the first question revealed that there is a lack of use of non-financial measures that they considered as contemporary management accounting practices as $26.6 \%$ of respondents said they never or rarely used non-financial measures related to customers and just $29.7 \%$ reported they often or very often used this measure. Non-financial measures related to employees was found to be little used in the Jordanian banks where $48.4 \%$ of respondents said they were never or rarely used. Non-financial measures related to employees and only $18.7 \%$ of respondents rated this measure as often or very often used.

According to respondents answers, economic value added or residual income measures, was found to be little used in the Jordanian banks since $56.3 \%$ of respondents ranked it never or rarely used, economic value added or 
residual income, and no more than $20.3 \%$ reported they often or very often used economic value added or residual income measure. Finally, benchmarks is considered as one of the most contemporary management accounting practices and rarely used, the research found that $67.2 \%$ of respondents rated benchmarks as never or rarely used in the Jordanian banks and just $20.3 \%$ were found often or very often used benchmarks. Table 1 below provides more illustration where the performance measures are exhibited according to their usage from the highest to the lowest.

Table 1. Usage of Performance evaluation measures

\begin{tabular}{llllllll}
\hline Usage of performance evaluation practices & Mean & S.D & 1 & 2 & 3 & 4 & 5 \\
\hline Financial measures & 4.25 & 0.959 & 1.6 & 3.1 & 17.2 & 25 & 53.1 \\
Non-financial measures related to operations and & 3.48 & 1.168 & 7.8 & 10.9 & 26.6 & 34.4 & 20.3 \\
innovation & & & & & & & \\
Non-financial measures related to customers & 3.08 & 1.131 & 9.4 & 17.2 & 43.8 & 15.6 & 14.1 \\
Non-financial measures related to employees & 2.53 & 1.284 & 28.1 & 20.3 & 32.8 & 7.8 & 10.9 \\
Economic value added or residual income & 2.38 & 1.175 & 29.7 & 26.6 & 23.4 & 17.2 & 3.1 \\
Benchmarks & 2.22 & 1.303 & 39.1 & 28.1 & 12.5 & 12.5 & 7.8 \\
\hline
\end{tabular}

1-Never; 2- Rarely; 3- Sometimes; 4-Often; 5-Very often

Moving to the second question in this section that was asked the respondents to rate the importance of the performance evaluation measures, the research found that almost all respondents considered all the Performance evaluation measures as important, even the contemporary measures which gives a strong indication to the future trend of these companies that might adopt these measures, since $73.4 \%$ of respondents rated the financial measures as important, $42.2 \%$ rated the non-financial measures related to customers as important. Non-financial measures related to operations and innovation, non-financial measures related to employees, benchmarks, and economic value added or residual income rated as important Performance evaluation measures by $37.5 \%, 35.9 \%$, $26.6 \%$ and $29.7 \%$ respectively where these measures have not been adopted widely. Therefore, and based on these figures the research could predict that the respondent companies intend to adopt those measures in the future, for more information see Table 2 below.

Table 2. Importance of performance evaluation measures

\begin{tabular}{lccccc}
\hline \multicolumn{1}{c}{ Importance of performance evaluation practices } & Mean & S.D & 1 & 2 & 3 \\
\hline Financial measures & 2.70 & 0.525 & 3.1 & 23.4 & 73.4 \\
Non-financial measures related to customers & 2.31 & 0.664 & 10.9 & 46.9 & 42.2 \\
$\begin{array}{l}\text { Non-financial measures related to operations } \\
\text { innovation }\end{array}$ & 2.27 & 0.648 & 10.9 & 51.6 & 37.5 \\
Non-financial measures related to employees & & & & & \\
Benchmarks & 2.22 & 0.678 & 14.1 & 50 & 35.9 \\
Economic value added or residual income & 2.03 & 0.712 & 23.4 & 50 & 26.6 \\
\hline
\end{tabular}

1- Not important; 2- Moderate important; 3-Important

\subsection{The Association between the Usage of Performance Evaluation Measures and Contingency Variables}

The current research will employ Bivariate analysis in order to find the association between two variables, and the appropriate non-parametric statistical test for the association between two variables that is applicable to the data is Kendall`s tau test. The Kendall's tau test is a product-moment, non-parametric correlation coefficient that deals with ranks (not magnitudes), and measures the strength of linear association between two (ordinal) variables (Sarantakos, 2007). Therefore, the research will use Kendall's tau test in order to discover the association between each of the contingency variables and performance evaluation measures as followed: 


\subsubsection{Organization Size}

The first association examination was carried out between the Performance evaluation measures and organization size variable as measured through three variables; age of the company since establishment; net sale growth; and number of employees in the respondent companies. Shown below are the results from each of these variables association with performance evaluation measures.

\subsubsection{The Age of the Company}

The results of the test revealed a significant positive association between the respondent companies' age that is represented by the number of years since establishment and the use of performance evaluation measures, as shown in Table 3 below.

\subsubsection{Net Sale Growth (Percentage)}

The results of the test reveal that there is a significant positive association between the net sale growth that is represented by the percentage of sale growth and the extent of use of performance evaluation measures, as shown in Table 3 below.

\subsubsection{Number of Employees}

Based on the findings shown in Table 3 below, the research indicates that there is a significant positive association between the number of employees and the extent of use of performance evaluation measures. According to the result above, there is a positive association between the size and the use of Performance evaluation measures and this is consistent with the previous researches, that asserted that there is a positive association between the size and the use of performance evaluation measures, for instance; Waweru, Hoque et al., 2004; Joshi, 2001; Hoque \& Mia, 2001, and Haldma \& Laats, 2002.

\subsubsection{Sophistication Level of Operations}

The second variable that was examined is the sophistication of operations presented by a number of products or services that the respondent companies produce or provided. According to the results in Table 3 below, the research reports that there is a significant positive association between the sophistication of operations and the extent of use of performance evaluation measures. The result of the above association is consistent with previous researches that revealed that there is a positive association between the sophistication of operations and the use of performance evaluation measures, for instance; Al-Omiri \& Drury (2007), Fry, Steele et al. (1995), Chenhall (2003).

\subsubsection{Professional Competence}

The third variable to be examined is the professional competence variable that was measured through two variables, mainly; number of academic degrees and number of professional certificates. Below are the results that are drawn from each of these variables associated with performance evaluation measures.

\subsubsection{Number of Academic Degrees}

As shown in Table 3 below, the research indicates that there is a significant association between the academic degrees and the performance evaluation measures; that means that there is vital role of education in adopting performance evaluation measures. The result is inconsistent with the previous researches that revealed that there is a gap between management accounting education and practice, and the significant role that management accounting education could play in order to adopt management accounting measures specially performance evaluation practices, for instance; Fowler, Tan et al. (2002), Burns, Hopper et al. (2004), Silvola (2005), Woodbine (2007), Yeung \& Armstrong (2001), Hassall \& Joyce (2001).

\subsubsection{Number of Professional Certificates}

The utilization of Kendall's tau correlation test indicated that there is a strong and significant positive association between the professional certificates and the use of performance evaluation measures, as shown in Table 3 below. This result indicated the important role that professional certificates such as CIMA play in order to facilitate and spread the awareness of the Performance evaluation measures that influence the usage of performance evaluation measures. Moreover, the result is consistent with previous researches that emphasized the major role that professional certificates play, for instance; Hassall \& Joyce (2001), Burns, Hopper et al. (2004), Forsaith, Tilt et al. (2001). 
Table 3. Kendall's tau correlation between contingent variables and the extent of use of performance evaluation measures

\begin{tabular}{lcc}
\hline \multicolumn{1}{c}{ Contingent Variables } & Correlation coefficient & Sig. (one-tailed) \\
\hline Age & $0.392^{* *}$ & 0.000 \\
Net sale growth & $0.242^{* *}$ & 0.008 \\
Number of employees & $0.193^{*}$ & 0.025 \\
Sophistication of operations & $0.258^{* *}$ & 0.004 \\
Academic degrees & $0.252^{* *}$ & 0.003 \\
Professional certificates & $0.279^{* *}$ & 0.002 \\
\hline
\end{tabular}

*. Correlation is significant at the 0.05 level (1-tailed).

**. Correlation is significant at the 0.01 level (1-tailed).

\section{Conclusions}

The main purposes of the current research were to explore the extent of usage of Performance evaluation measures and to examine the main contingent variables that influence the extent of usage of Performance evaluation measures in the Jordanian banks. The research indicated that there is a lack of use of non-financial measures that are considered as contemporary management accounting practices, and on the other hand, the financial measures were considered as the highest practice being utilised, i.e. they were classified as one of the traditional management accounting practices. However, based on the analysis of the importance of contemporary practices, the research predicted that companies intend to adopt these measures in the future. In addition, the research suggested that the future trend of the Jordanian banking sector in terms of the measures that would become extinct, and the measures that would be most prevalently used in the future. Accordingly, the research revealed that measures such as, benchmarks practice would be used in the future. Financial measures were predicted to be more prevalently used in the future.

In terms of testing the hypotheses that are related to the association between each contingency variables and the extent of usage of performance evaluation measures, the research confirmed and supported all hypotheses that were tested in the current research, namely; age of the company (number of years since establishment); net sale growth, number of employees; sophistication of operations; professional certificates; and academic certificates. The research is consistent with previous studies that indicated that traditional Performance evaluation measures are still widely used and provides evidence of the contingent variables that influence the extent of usage of performance evaluation measures in the Jordanian banks. Additionally, the banking sector is a crucial sector that has a significant impact on the economy, and requires accurate and timely information. Consequently, the research encourages the companies to adopt advanced performance evaluation measures, since the results revealed there is a lack of adoption of these measures.

\section{References}

Abdel-Kader, M., \& Luther, R. (2006). Management accounting practices in the British food and drinks industry. British Food Journal, 108(5), 336-357. http://dx.doi.org/10.1108/00070700610661321

Abdel-Kader, M., \& Luther, R. (2008). The impact of firm characteristics on management accounting practices: A UK-based empirical analysis. British Accounting Review, 40(1), 2-27. http://dx.doi.org/10.1016/j.bar.2007.11.003

Adelegan, O. J. (2000). Management accounting practices in Nigerian companies. Nigeria: University of Ibaden.

Ahmad B. Abdel-Maksoud. (2004). Manufacturing in the UK: contemporary characteristics and performances indicators. Journal of manufacturing technological management, 15(2), 155-171.

Ahmed, A. (2003). The level of IT/IS skills in accounting programmes in British universities. Management Research News, 26(12), 20-58. http://dx.doi.org/10.1108/01409170310783709

Al-Omiri, M., \& Drury, C. (2007). A survey of factors influencing the choice of product costing systems in UK organizations. Management Accounting Research, 18(4), 399-424. http://dx.doi.org/10.1016/j.mar.2007.02.002

Ashton, D., Hopper, T., \& Scapens, R. (1995). The changing nature of issues in management accounting. 
London: Prentice Hall.

Bamber, L. S., Braun, K. W., \& Harrison, W. T. (2007). Managerial accounting. Upper Saddle River, NJ.: Pearson Prentice Hall.

Billings, M., \& Capie, F. (2004). The development of management accounting in UK clearing banks, 1920-70. Accounting Business and Financial History, 14(PART 3), 317-338. http://dx.doi.org/10.1080/0958520042000277793.

Burns, J., Hopper, T., \& Yazdifar, H. (2004). Management accounting education and training: putting management in and taking accounting out. Qualitative Research in Accounting \& Management, 1(1), 1-29. http://dx.doi.org/10.1108/11766090410816271

Carmona, S. (2006). The history of management accounting in France, Italy, Portugal, and Spain. In Christopher S. Chapman, Anthony G. Hopwood \& Michael D. Shields (Eds.), Handbooks of management accounting research, 905-922. http://dx.doi.org/10.1016/S1751-3243(06)02018-9

Chan, A. M. Y., Chan, N. P. M., \& Lui, K. K. (1997). Management accounting practices and market performance of the Chinese listed companies. Asian-Pacific Conference on International Accounting Issues, (9TH), 171-173.

Chandra. A., Cheh. J., \& Kim, I. (2007). Do we teach enough IT skills in management accounting courses? Management Accounting Quarterly, 8(1), 49-54.

Chenhall, R. H. (2003). Management control systems design within its organizational context: findings from contingency-based research and directions for the future. Accounting Organisations and Society, 28(2-3), 127-168. http://dx.doi.org/10.1016/S0361-3682(01)00027-7

Christopher, W. F. (2004). Best practices in management accounting? Journal of Cost Management, 18(PART 4), 33-37.

Cinquini, L., \& Tenucci, A. (2006). Strategic management accounting: Exploring distinctive features and links with strategy.

Clarke, P. J. (1997). Management accounting practices in large Irish manufacturing firms. Ibar-Dublin, 18, 136-152.

Clarke, P., Hill, N., \& Stevens, K. (1996). Management accounting practices in Ireland. Accountancy Ireland, 28(3), 20-21.

Cooper, P. (2006). Adapting management accounting knowledge needs to functional and economic change. Accounting Education London, 15(NUMB 3), 287-300. http://dx.doi.org/10.1080/09639280600850760

Ewert, R., \& Wagenhofer, A. (2006). Management accounting theory and practice in German-speaking countries. In Christopher S. Chapman, Anthony G. Hopwood \& Michaell D. Shields (eds.), Handbooks of management accounting research, Elsevier, 1035-1069. http://dx.doi.org/10.1016/S1751-3243(06)02021-9

Flacke, K., \& Segbers, K. (2005). Does management accounting follow entrepreneurial characteristics? Results of an empirical analysis of German SME. Germany: University of Munster.

Fleischman, R., \& Tyson, T. (2006). The history of management accounting in the U.S. In Christopher S. Chapman, Anthony G. Hopwood \& Michael D. Shields (Eds.), Handbooks of management accounting research, Elsevier, 1071-1089. http://dx.doi.org/10.1016/S1751-3243(06)02022-0

Forsaith, D., Tilt, C., \& Xydias-Lobo, M. (2001). The future of management accounting: a South Australian perspective. School of Commerce Research Paper, pp. 1-20.

Fowler, M., Tan, L. M., \& Hawkes, L. (2002). Management accounting education: Is there a gap between teaching and practice? Chartered Accountants Journal of New Zealand, 81(PART 10), 58.

Fry, T. D., Steele, D. C., \& Saladin, B. A. (1995). The role of management accounting in the development of a manufacturing strategy. International Journal of Operations and Production Management, 15(12), 21-31. http://dx.doi.org/10.1108/01443579510104475

Garg, A., Ghosh, D., \& Halper, H. (2004). Best practices in management accounting. Journal of Cost Management, 18(PART 2), 21-25.

Gupta, K. M., \& Gunasekaran, A. (2005). Costing in new enterprise environment: A challenge for managerial accounting researchers and practitioners. Managerial Auditing Journal, 20(4), 337-353. http://dx.doi.org/10.1108/02686900510592034 
Haldma, T., \& Laats, K. (2002). Contingencies influencing the management accounting practices of Estonian manufacturing companies. Management Accounting Research, 13(Part 4), 379-400. http://dx.doi.org/10.1006/mare.2002.0197

Hassall, T., \& Joyce, J. (2001). Approaches to learning of management accounting students. Education and Training, 43(Part 2/3), 145-152. http://dx.doi.org/10.1108/00400910110394071

Hoque, Z., \& Mia, L. (2001). Market competition, computer-aided manufacturing and use of multiple performance measures: an empirical study. British Accounting Review, 33(Part 1), 23-46. http://dx.doi.org/10.1006/bare.2000.0149

Hussain, M. M., \& Gunasekaran, A. (2002). An institutional perspective of non-financial management accounting measures: a review of the financial services industry. Managerial Auditing Journal, 17(9), 518-536. http://dx.doi.org/10.1108/02686900210447524

Hutaibat, K. A. (2005). Management accounting practices in Jordan - a contingency approach. Bristol: University of Bristol.

Hyvonen, J. (2005). Adoption and benefits of management accounting systems: Evidence from Finland and $\begin{array}{lllll}\text { Australia. Advances in International Accounting, } & \text { 18, }\end{array}$ http://dx.doi.org/10.1016/S0897-3660(05)18005-2

Islam, M., \& Kantor, J. (2005). The development of quality management accounting practices in China. Managerial Auditing Journal, 20(7), 707-724. http://dx.doi.org/10.1108/02686900510611249

Ismail, T. H. (2007). Performance evaluation measures in the private sector: Egyptian practice. Managerial Auditing Journal, 22(5), 503-513. http://dx.doi.org/10.1108/02686900710750775

Ittner, C. D., Larcker, D. F., \& Randall, T. (1998). The Activity-Based Cost Hierarchy, Production Policies and Firm Profitability. Journal of Management Accounting Research, 9, 143-162.

Johnson, H. T., \& Kaplan, R. (1991). The relevance lost: the rise and fall of management accounting. Boston, Mass.: Harvard Business School.

Joshi, P. L., \& Bremser, G. (2004). Changing dimensions of accountants' role and skill requirements in organisations: findings from the corporate sector in Bahrain. Int. J. Accounting, Auditing and Performance Evaluation, 1(3), 363-384. http://dx.doi.org/10.1504/IJAAPE.2004.005926

Kallunki, J. \& Silvola, H., (2007). The effect of organizational life cycle stage on the use of activity-based costing. Management Accounting Research, 19(1), 62-79. http://dx.doi.org/10.1016/j.mar.2007.08.002

Kattan, F., Pike, R., \& Tayles, M. (2007). Reliance on management accounting under environmental uncertainty: The case of Palestine. Journal of Accounting and Organizational Change, 3(3), 227-249. http://dx.doi.org/10.1108/18325910710820283

Kowalak, R. (2007). Implementation of best practices in management accounting. Prace Naukowe- Akademii Ekonomicznej Imienia Oskara Langego we Wroclawiu, (1178), 63-69.

Lord, R., \& Robertson, J. (2006). Students' experiences of learning in a third-year management accounting class: evidence from New Zealand. Accounting Education, 15(1), 41-59. http://dx.doi.org/10.1080/06939280600581053

Marelli, A., Miolo, P., \& Giannetti, R. (2002). A survey on non financial measure practices in Italian management accounting Systems. Annual Congress, (25), D20-03.

Mia, M. A. H., \& Ahmad, F. (2005). Strategic management accounting practices in the 21 st Century. The Cost and Management, 33(4), 44-49.

NÄsi, S., \& Rohde, C. (2006). Development of cost and management accounting ideas in the Nordic countries. In Christopher S. Chapman, Anthony G. Hopwood \& Michael D. Shields (eds.), Handbooks of Management Accounting Research, Elsevier, 1091-1118. http://dx.doi.org/10.1016/S1751-3243(06)02023-2

Okano, H., \& Suzuki, T. (2006). A history of Japanese management accounting. In Christopher S. Chapman, Anthony G. Hopwood \& Michael D. Shields (eds.), Handbooks of management accounting research, Elsevier, 1119-1137. http://dx.doi.org/10.1016/S1751-3243(06)02024-4

Otley, D. T. (1980). The contingency theory of management accounting: achievement and prognosis. Accounting Organisations and Society, 4, 413-428. http://dx.doi.org/10.1016/0361-3682(80)90040-9

Palmer, K. N., Ziegenfuss, D. E., \& Pinsker, R. E. (2004). International knowledge, skills, and abilities of 
auditors/accountants: Evidence from recent competency studies. Managerial Auditing Journal, 19(7), 889-896. http://dx.doi.org/10.1108/02686900410549411

Sarantakos, S. (2007). A toolkit for quantitative data analysis using SPSS. New York: Palgrave Macmiillan.

Shields, M. D., Chow, C. W., Kao, Y., \& Nakagawa, Y. (1991). Management accounting practices in the U.S. and Japan: Comparative survey findings and research implications. Journal of International Financial Management and Accounting, 3(1), 60-77. http://dx.doi.org/10.1111/j.1467-646X.1991.tb00091.x

Siegel, G. (2000). Skills needed for entry-level management accounting positions. Strategic Finance -Montvale, (APR), 79-80.

Silvola, H. (2005). Management accounting practices (A contingency perspective based on the organizational life cycle, venture capital investors and the education of $C E O$ ). Oulu- Finland: University of Oulu.

Spraakman, G., \& Margret, J. (2005). The transfer of management accounting practices From London counting houses to the British North American fur trade. Business \& Financial History, 15(2), 101-119. http://dx.doi.org/10.1080/09585200500121108

Spraaknam, G. P. (1999). Management accounting at the historic Hudson's Bay Company: A comparison to 20th century practices. Accounting Historians Journal, 26(2), 35-64.

Strauss, P. S. (1992). Managing change (Management of an accounting practice). New York: New York State Society of CPAs.

Sulaiman, M. B., Ahmad, N. N., \& Alwi, N. (2004). Management accounting practices in selected Asian countries: A review of the literature. Managerial Auditing Journal, 19(4), 493-508. http://dx.doi.org/10.1108/02686900410530501

Triest, S. V., \& Elshahat, M. F. (2007). The use of costing information in Egypt: a research note. Journal of Accounting and Organizational Change, 3(3), 329-343. http://dx.doi.org/10.1108/18325910710820328

Waweru, N. M., Hoque, Z., \& Uliana, E. (2004). Management accounting change in South Africa: Case studies from retail services. Accounting, Auditing \& Accountability Journal, 17(5), 675-704. http://dx.doi.org/10.1108/09513570410567773

Wijewardena, H., \& D. E Zoysa, A. (1998). A comparative analysis of management accounting practices in Australia and Japan: an empirical investigation. Asian-Pacific Conference on International Accounting Issues, (10th), 72-76.

Woodbine, G. F. (2007). Accounting education in modern China: an analysis of conditions and observations. Asian Review of Accounting, 15(1), 62-71. http://dx.doi.org/10.1108/13217340710763753

Yeung, V. W. S., \& Armstrong, R. W. (2001). The effect of education level on the adoption of total quality management principles and practices among Hong Kong managers. International Journal of Management, 18(Part 2), 213-221. 